\title{
Near Surface Carbon Dioxide and Methane in Urban Areas of Costa Rica
}

\author{
Germain Esquivel-Hernández ${ }^{1,2 *}$, Mario Villalobos-Forbes², Ricardo Sánchez-Murillo², \\ Christian Birkel ${ }^{3,4}$, Juan Valdés-González ${ }^{1}$, Jan Boll ${ }^{5}$ \\ ${ }^{1}$ Laboratorio de Química de la Atmosfera, Escuela de Química, Universidad Nacional, Heredia, Costa Rica \\ ${ }^{2}$ Grupo de Investigación en Isotopos Estables, Escuela de Química, Universidad Nacional, Heredia, Costa Rica \\ ${ }^{3}$ Escuela de Geografía, Universidad de Costa Rica, San José, Costa Rica \\ ${ }^{4}$ Northern Rivers Institute, University of Aberdeen, Aberdeen, UK \\ ${ }^{5}$ Department of Civil and Environmental Engineering, Washington State University, Pullman, USA \\ Email: *germain.esquivel.hernandez@una.cr
}

Received 26 October 2015; accepted 11 December 2015; published 14 December 2015

Copyright (C) 2015 by authors and Scientific Research Publishing Inc.

This work is licensed under the Creative Commons Attribution International License (CC BY).

http://creativecommons.org/licenses/by/4.0/

(c) (;) Open Access

\section{Abstract}

Little information is available for Central America regarding methane and carbon dioxide mixing ratios in urban areas. This work reports a representative spatial and seasonal study of near surface carbon dioxide and methane, carried out between July 2014 and January 2015 (27 weeks) in the Central Valley of Costa Rica, and other urban and rural sites across the country and covering three distinct seasons: Mid-summer drought (July-August), wet season (September-November) and transition period (December-January). The mixing ratios of both gases are clearly influenced by the metropolitan area, and by the prevailing atmospheric conditions during the wet season months. Average carbon dioxide concentration $(629 \pm 80 \mathrm{ppm})$ and average methane concentration $(2192 \pm 110 \mathrm{ppb})$ were up to $8 \%$ and up to $10 \%$, respectively, higher during the wet season than the values recorded outside this period. HYSPLIT back air mass trajectories analysis, and weather data available for the Central Valley, suggest that these differences arise as result of a reduction in the mixing layer of depth $(\sim 425 \mathrm{~m})$ and the wind speed $(\sim 1.5 \mathrm{~m} / \mathrm{s})$ across the valley, favoring the accumulation of polluted air masses in the metropolitan area. Other natural and anthropogenic sources, like the volcanic emissions of the Turrialba Volcano and the livestock activities at rural sites, apparently influence the mixing ratios of both gases across Costa Rica. Although the scope of this study is limited to representative seasonal conditions of the Central Valley in 2014 and 2015, it is possible considering the information presented in this work that the "dome" phenomenon can be assumed to exist.

\section{Keywords}

Carbon Dioxide, Methane, Urban Areas, Costa Rica, HYSPLIT, Atmospheric Conditions

\footnotetext{
${ }^{*}$ Corresponding author.

How to cite this paper: Esquivel-Hernández, G., Villalobos-Forbes, M., Sánchez-Murillo, R., Birkel, C., Valdés-González, J. and Boll, J. (2015) Near Surface Carbon Dioxide and Methane in Urban Areas of Costa Rica. Open Journal of Air Pollution, 4, 208-223. http://dx.doi.org/10.4236/ojap.2015.44018
} 


\section{Introduction}

For more than 50 years, the atmospheric monitoring done at Mauna Loa, Hawaii, and the South Pole, has allowed scientists to track greenhouse and other trace gases in the global atmosphere [1] [2]. As a general conclusion of this monitoring effort, the long-lived greenhouse gases $(\mathrm{GHG})$ methane $\left(\mathrm{CH}_{4}\right)$, nitrous oxide $\left(\mathrm{N}_{2} \mathrm{O}\right)$ and carbon dioxide $\left(\mathrm{CO}_{2}\right)$ are now recognized as primary contributors to global warming [3]-[6]. Their anthropogenic sources (motorized transport, industrial processing, electric power plants, incomplete combustion of fossil fuels and their escape, sewage collectors, settling tanks, landfills and others) contribute significantly to the content of these gases in the atmosphere, as a whole, and especially in its surface layer [5] [7]-[8].

Urban and suburban areas, despite covering only 2\% of the Earth's surface, are responsible for a large fraction of greenhouse gas emissions to the atmosphere, accounting for 30\% - 40\% of global anthropogenic emissions [9] [10]. This has resulted in an increasing number of measurements of atmospheric $\mathrm{CO}_{2}$ mixing ratios in cities, as a mean of studying local GHG emissions, urban carbon cycles, and the spatial distribution in large urban regions [11]-[14]. Carbon dioxide, water vapor and energy flux data suggest that domes of high $\mathrm{CO}_{2}$ levels form over cities, revealing at the same time, that they are an important source of the global carbon budget [11] [15]. An urban $\mathrm{CO}_{2}$ dome is formed when within the two-meter-height atmospheric layer located near the surface, high $\mathrm{CO}_{2}$ levels are present in the range 500 - 600 ppm. Typically, these concentrations diminished from the city center towards the outlying rural areas and their presence is related with air temperature inversions at night and in the early morning, but also with local atmospheric features, such as air mass circulation patterns [7] [8] [16]. Isotopic analysis of $\mathrm{CO}_{2}$ has been useful to study such phenomenon and to identify the sources of local emission, the influence of atmospheric stability as well as the height of the atmospheric mixing layer on $\mathrm{CO}_{2}$ levels [17][19]. However, while the urban sources of $\mathrm{CO}_{2}$ have been extensively studied, there has been a paucity of observational studies of $\mathrm{CH}_{4}$ emissions and other less-abundant GHG in urban environments [6]. Methane has a global warming potential of about 25 times that of $\mathrm{CO}_{2}$ on a 100 year time scale [20]. While the global emissions of $\mathrm{CH}_{4}$ are relatively well constrained, regional emissions and the contribution of individual sources are not [21] [22]. In urban areas, $\mathrm{CH}_{4}$ is mainly released from landfills and wastewater treatment plants, fossil fuel and biomass burning, but also from surrounding natural sources like wetlands [6] [22] [23].

Additionally, little has been published on Central and South American $\mathrm{CH}_{4}$ and $\mathrm{CO}_{2}$ mixing ratios in urban areas [24]. To the best of our knowledge, no systematic information about near surface GHG levels is available for Costa Rican urban areas. Reference [25] presented a demonstration for urban contamination mapping using a quadruple based mass spectrometer system, which included in-situ data of helium, $\mathrm{CO}_{2}$, sulfur dioxide, and other gas species. While driving on a highway in the Central Valley of Costa Rica, $\mathrm{CO}_{2}$ levels as high as 1000 ppm were recorded. Thus, a greater understanding of spatial and temporal variations of near surface GHG in tropical regions like Costa Rica is necessary to promote atmospheric research of this nature.

This work is part of an on-going effort to establish a long-term GHG monitoring station in the metropolitan area of Costa Rica. The present data were gathered during a representative seasonal investigation of near surface $\mathrm{CH}_{4}$ and $\mathrm{CO}_{2}$, based on the analysis of samples collected at weekly intervals during July 2014-January 2015 at six locations, in order to 1) investigate the seasonal influence on $\mathrm{CO}_{2}$ and $\mathrm{CH}_{4}$ concentrations in the metropolitan area and surrounding areas inside the Central Valley, in combination with HYSPLIT back air mass trajectory analysis, and 2) compare the $\mathrm{CO}_{2}$ and $\mathrm{CH}_{4}$ levels with other urban, rural and protected areas located across the continental divide of the country. These data can be used to address potential future changes of GHG emissions in urban conglomerates like the metropolitan area of Costa Rica, which may have a significant impact on the strength and distribution of major GHG emissions, in particular $\mathrm{CO}_{2}$, into the atmosphere in tropical regions like Central America.

\section{Study Area}

The Central Valley is characterized by an urban conglomerate, known as the metropolitan area, which comprises the four major cities of Costa Rica ( $\sim 60 \%$ population, $\sim 870$ inhabitants per $\mathrm{km}^{2}$ ) and includes significant industrial activity. The available road system inside the valley can be described as a slow-moving traffic network, with an average traffic of $\sim 80,000$ vehicles per day. Especially during the rush hours, this traffic pattern increases the amount of vehicle-related pollutants emitted into the air [26]. Weather conditions in the valley are mainly influenced by easterly Caribbean trade winds during the dry season (February-April) and by frequent westerly continental air masses during the wet season (May-October). In this region, mean annual precipitation ranges 
from $\sim 3500 \mathrm{~mm}$ in the highlands to $\sim 2000 \mathrm{~mm}$ in the foothills, and the area experiences 3 - 4 dry months over the dry season. This inter-mountainous valley region has an elevation between 1000 and 2500 meters m.a.s.l, with annual average temperatures that range from $14^{\circ} \mathrm{C}$ to $20^{\circ} \mathrm{C}$ according to elevation [27]. Table 1 summarizes the average weather data recorded at Heredia (the main monitoring station) during July 2014-January 2015. Other urban areas located outside the valley are characterized by less intensive industrial activity, but important agricultural activities. The population living in these urban areas is $~ 550,000$ inhabitants, with an average density $\sim 170$ inhabitants per $\mathrm{km}^{2}$.

\section{Materials and Methods}

\subsection{Sampling Campaigns}

Samplings campaigns were conducted from July 2014 to January 2015. The sampling period was selected based on the climatic features of Costa Rica, which are influenced by four regional air circulation processes: northeast trade winds (i.e. alisios), the latitudinal migration of the Intertropical Convergence Zone (ITCZ), cold continental

Table 1. Sampling site characteristics including geographic coordinates (decimal degrees), elevation, site classification and sampling period.

\begin{tabular}{|c|c|c|c|c|c|}
\hline Site & $\begin{array}{l}\text { Longitude } \\
\text { (dec.deg) }\end{array}$ & $\begin{array}{l}\text { Latitude } \\
\text { (dec.deg) }\end{array}$ & $\begin{array}{c}\text { Elevation } \\
\text { (ma.s.l.) }\end{array}$ & Classification & Sampling period \\
\hline Cipresal & -84.12171 & 10.08510 & 1732 & Rural & Jul. 14-Jan. 15 \\
\hline Heredia & -84.11119 & 9.99879 & 1159 & Urban & Jul. 14-Jan. 15 \\
\hline Guachipelín & -84.16112 & 9.94401 & 990 & Urban & Jul. 14-Jan. 15 \\
\hline Turrúcares & -84.31794 & 9.95990 & 640 & Rural & Jul. 14-Jan. 15 \\
\hline San José & -84.07705 & 9.93385 & 1170 & Urban & Jul. 14-Jan. 15 \\
\hline Rancho Redondo & -83.95259 & 9.95905 & 2045 & Rural & Jul. 14-Jan. 15 \\
\hline La Cruz & -85.64019 & 11.07019 & 255 & Urban & Dec. 14-Jan. 15 \\
\hline Murciélago & -85.72630 & 10.89190 & 106 & Protected area & Dec. 14-Jan. 15 \\
\hline Orosí Volcano & -85.49572 & 10.95756 & 578 & Protected area & Dec. 14-Jan. 15 \\
\hline Turrialba Volcano & -83.78919 & 10.00283 & 2679 & Rural & Dec. 14-Jan. 15 \\
\hline Capellades & -83.78586 & 9.92233 & 1680 & Urban & Dec. 14-Jan. 15 \\
\hline Pacayas & -83.80569 & 9.91519 & 1741 & Urban & Dec. 14-Jan. 15 \\
\hline Herradura & -84.65947 & 9.66222 & 112 & Urban & Dec. 14-Jan. 15 \\
\hline Braulio Carrillo & -83.94858 & 10.14731 & 507 & Protected area & Dec. 14-Jan. 15 \\
\hline Bataan & -83.37628 & 10.09819 & 43 & Urban & Dec. 14-Jan. 15 \\
\hline Monteverde & -84.79572 & 10.30750 & 1520 & Protected area & Dec. 14-Jan. 15 \\
\hline Sardinal & -84.85134 & 10.17032 & 495 & Urban & Dec. 14-Jan. 15 \\
\hline Caldera & -84.71425 & 9.92134 & 5 & Urban & Dec. 14-Jan. 15 \\
\hline Horquetas & -83.92266 & 10.31854 & 83 & Urban & Dec. 14-Jan. 15 \\
\hline Ciudad Quesada & -84.430942 & 10.32309 & 665 & Urban & Dec. 14-Jan. 15 \\
\hline Zarcero & -84.391521 & 10.184689 & 1740 & Urban & Dec. 14-Jan. 15 \\
\hline Orotina & -84.523723 & 9.911922 & 235 & Urban & Dec. 14-Jan. 15 \\
\hline Labrador, Alajuela & -84.612547 & 9.942665 & 165 & Rural & Dec. 14-Jan. 15 \\
\hline Golfito & -83.168315 & 8.641935 & 15 & Urban & Dec. 14-Jan. 15 \\
\hline Ciudad Neilly & -82.941738 & 8.648863 & 33 & Urban & Dec. 14-Jan.15 \\
\hline Buenos Aires & -83.321621 & 9.150613 & 375 & Urban & Dec. 14-Jan.15 \\
\hline
\end{tabular}


outbreaks (i.e. northerly winds), and sporadic influence of Caribbean cyclones [28]. These circulation processes produce a distinctive circulation pattern for the Central Valley. During the wet season (May-October), the air masses arriving in Costa Rica can be classified as continental winds, reaching Costa Rica's Central Valley from the Pacific Ocean. Most of these air masses move over the major industrial and urban areas of the country. In the dry season (February-April), trade winds bring air masses to Costa Rica originating from the Caribbean Sea, and they move over non-industrial and less populated areas. Air masses arriving over Costa Rica during the transition period can be transported by continental or trade-winds, as a result of a weakening in the trade winds reaching Costa Rica. The influence of the wind circulating pattern is also observed in the precipitation regime, resulting in two rainfall maxima, one in June and one in September, which are interrupted by a relative minimum between July-August known as the Mid-Summer Drought (i.e. intensification of the trade winds over the Caribbean Sea) [29]. For this study, the transition period 2014-2015 was estimated as the period between midNovember and late January, where increasing wind speed and decreasing precipitation were observed for the study site (Table 2). A more detailed description of meteorological conditions prevailing in the Central Valley of Costa Rica was recently reported by Sánchez-Murillo et al. [41].

The distribution of sampling sites across Costa Rica is shown in Figure 1 and a summary of their characteristics are listed in Table 2. Six sampling sites inside the metropolitan area and surrounding rural areas were selected to study the seasonal variation of near surface $\mathrm{CO}_{2}$ and $\mathrm{CH}_{4}$ levels (Figure 2). Sampling frequency was

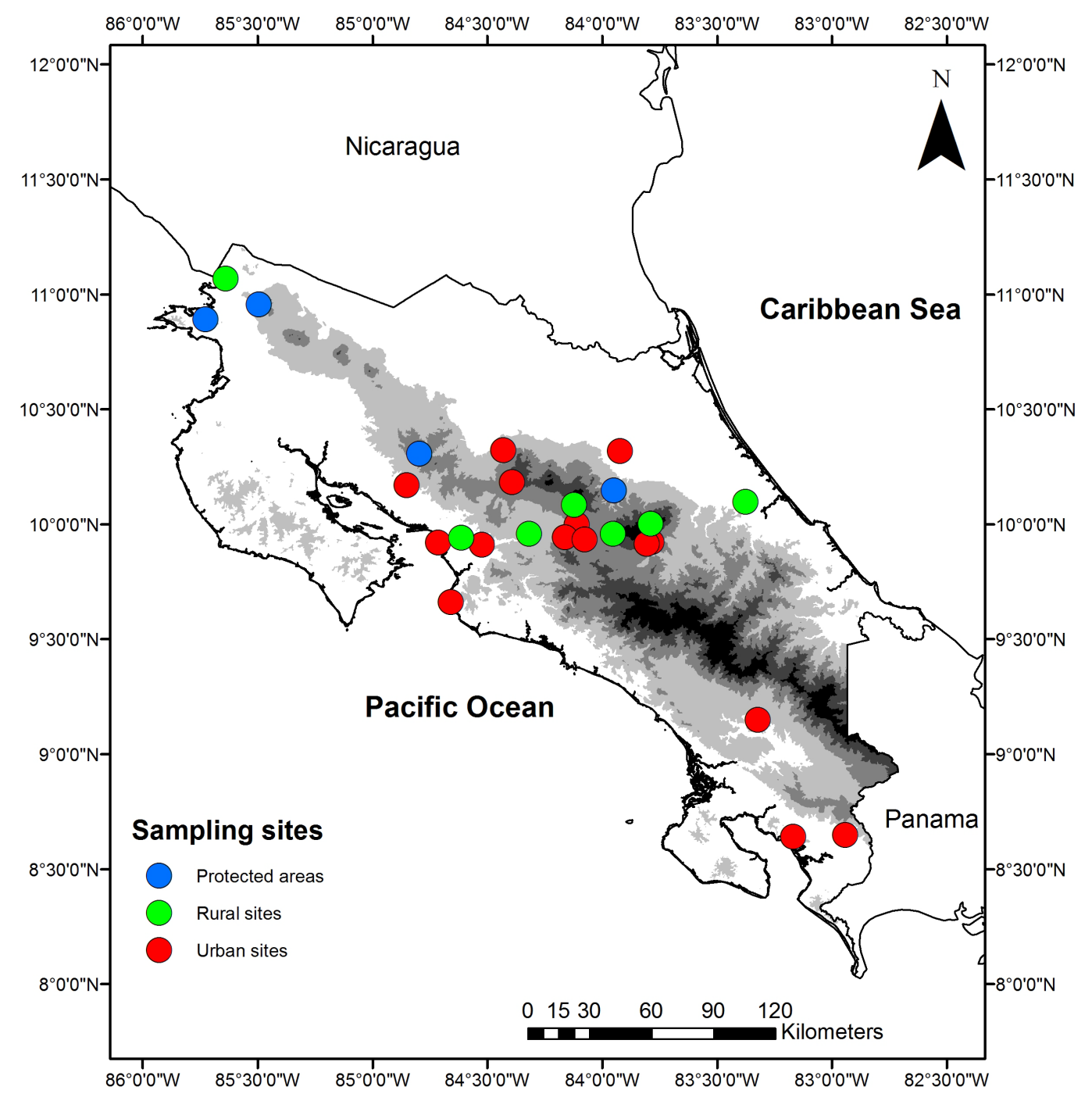

Figure 1. Sampling site locations across the Costa Rican territory. 


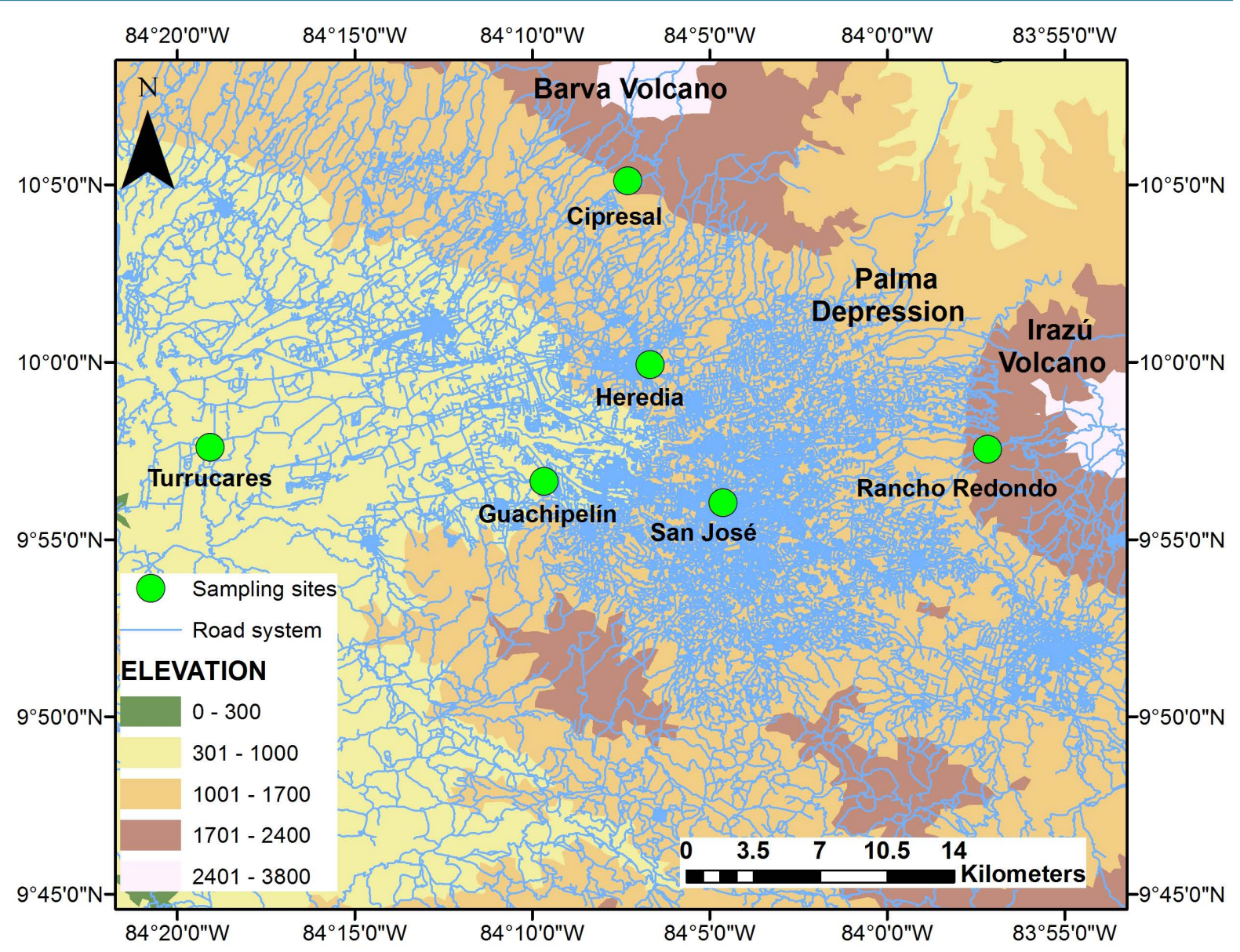

Figure 2. Weekly sampling site locations in the Central Valley of Costa Rica.

Table 2. Summary of monthly weather data recorded at the Heredia sampling site.

\begin{tabular}{|c|c|c|c|c|c|}
\hline Month & $\begin{array}{l}\text { Mean temperature } \\
\left({ }^{\circ} \mathrm{C}\right)\end{array}$ & $\begin{array}{l}\text { Relative humidity } \\
\text { (\%) }\end{array}$ & $\begin{array}{l}\text { Wind speed } \\
(\mathrm{m} / \mathrm{s})\end{array}$ & Wind direction & $\begin{array}{l}\text { Total precipitation } \\
\text { (mm) }\end{array}$ \\
\hline July 2014 & 21.9 & 78.9 & 1.83 & ESE & 63.2 \\
\hline August 2014 & 21.6 & 79.4 & 1.14 & $\mathrm{SE}$ & 166.6 \\
\hline September 2014 & 21.2 & 83.9 & 0.82 & SE & 680.1 \\
\hline October 2014 & 21.5 & 83.5 & 0.78 & SSE & 90.9 \\
\hline November 2014 & 21.7 & 76.9 & 1.48 & ESE & 35.1 \\
\hline December 2014 & 21.3 & 74.7 & 2.05 & ESE & 15.9 \\
\hline January 2015 & 20.1 & 72.7 & 3.17 & ENE & 4.7 \\
\hline
\end{tabular}

weekly and samples were collected typically in the morning (from 09:00 to 11:00). In October 2014 and January 2015, a high frequency sampling was carried out at Heredia. Samples were collected at half-hourly intervals for 24 hours in order to establish the short term variability of GHG concentrations during both wet season and transition period. GHG levels at these six sites within the Central Valley were also compared to the other representative urban areas, rural sites and protected areas across the country. The sampling done at these other areas located outside the valley was carried out during the transition period December 2014-January 2015 only. A Mann-Whitney Rank Sum non-parametric test (95\% confidence) was conducted to determine significant differences in the $\mathrm{CO}_{2}$ and $\mathrm{CH}_{4}$ mixing ratios of sampling sites located in the Central Valley. 


\subsection{Sampling and Analytical Methods}

The air samples were collected by pumping air into $2-5$ liter Tedlar bags at a height of $2-3 \mathrm{~m}$ above the ground. Mixing ratios of atmospheric $\mathrm{CO}_{2}$ and $\mathrm{CH}_{4}$ were measured in all air samples in the Laboratorio de Química de la Atmósfera at Universidad Nacional, Heredia, within 24 hours after sample collection. For all air samples, the $\mathrm{CO}_{2}$ and $\mathrm{CH}_{4}$ mixing ratios were determined using a SRI Instruments 8610C gas chromatograph (GC) with a flame ionization detector (FID) and a methanizer $\left(\mathrm{CO}_{2}\right.$ analysis) with a repeatability of $\pm 1.1 \mathrm{ppm}$ for $\mathrm{CO}_{2}$ and $\pm 71 \mathrm{ppb}$ for $\mathrm{CH}_{4}$. The GC instrument was calibrated for $\mathrm{CO}_{2}$ in the range of 400 to $1000 \mathrm{ppm}$ and for $\mathrm{CH} 4$ from 1750 to $3500 \mathrm{ppb}$ using commercially available standards (Scott Specialty Gases, USA). Stability and quality control standards consisted of dried Heredia ambient air, pressurized into high pressure cylinders using a diving compressor. All measurements were triplicated.

\subsection{HYSPLIT Back Air Mass Trajectories}

Air parcel back trajectories were calculated for the Heredia sampling site using the Hybrid Single Particle Lagrangian Integrated Trajectory model (HYSPLIT) [30]. Single 48 hours back trajectories were calculated using the vertical velocity model calculation method. Trajectory ensembles were done using the GDAS1 meteorological database. Back trajectories were calculated starting at 1800 UTC. Rainfall rate, downward radiation, relative humidity, and elevation of the mixing layer depth were also computed. A Pearson Product Moment correlation analysis was applied to assess potential relationships between the observed GHG mixing ratios and the ground meteorological and HYSPLIT computed data at the Heredia site.

\section{Results and Discussion}

\subsection{Seasonal and Diel Patterns in Near Surface $\mathrm{CO}_{2}$ and $\mathrm{CH}_{4}$ in the Central Valley}

The $\mathrm{CO}_{2}$ and $\mathrm{CH}_{4}$ mixing ratios recorded at the Central Valley sampling sites are shown in Figure 3 and Figure 4, respectively, which compare sampling sites located inside the metropolitan area with those located outside the urban conglomerate. The seasonal cycle of near surface $\mathrm{CO}_{2}$ and $\mathrm{CH}_{4}$ is characterized by greater mixing ratios of both gases during the wet season than those recorded during the mid-summer drought and the transition period (Table 3). At these sites, the influence of wind direction on the pollutant transport pattern is located on the NE-SW axis across the valley. For the metropolitan area, and during the wet season, the average $\mathrm{CO}_{2}$ mixing ratio $(629 \pm 80 \mathrm{ppm})$ was $7 \%$ - 8\% significantly higher than the corresponding average values recorded during the mid-summer drought and the transition period ( $p=0.033$ and 0.046 , respectively). The average concentration outside the urban conglomerate (583 $\pm 32 \mathrm{ppm}$ ) during the wet season was $13 \%$ higher than in the mid-summer drought $(p<0.001)$, but not statistically significantly higher than in the transition period, which was only $2 \%$ higher $(p=0.334)$. Near surface $\mathrm{CH}_{4}$ followed a similar pattern, except for the sites located in the metropolitan area. In this area, the wet season average concentration (2192 $\pm 110 \mathrm{ppb})$ was $10 \%$ higher than the mixing ratio measured in July-August 2014 and 2\% higher than the recorded values in November 2014-January 2015. However, both increases are not statistically significant ( $p=0.137$ and 0.798 , respectively). Outside the more populated areas, the average concentration during the wet season was $2200 \pm 145 \mathrm{ppb}$ and was $12 \%$ significant higher than in the mid-summer drought $(p=0.033)$, but the observed increase of only $1 \%$ in the transition period is not statistically significant $(p=0.871)$. The increasing mixing ratios of both gases during the wet season might be related with the observed decrease in the average wind speed inside the valley $(\sim 1.5 \mathrm{~m} / \mathrm{s})$, which reduces the transport of pollutants in direction S-SW (see Table 2). However, it is apparent from Figure 3 and Figure 4 that the sampling sites located along the S-SW-W axis in the Central Valley, Guachipelín and Turrúcares, are influenced by the air masses transported from the heavy populated urban area, which increases the mixing ratios of both gases to concentrations as high as $750-900 \mathrm{ppm}\left(\mathrm{CO}_{2}\right)$ and $3000-3500 \mathrm{ppb}\left(\mathrm{CH}_{4}\right)$. A similar transport pattern has been reported in other urban areas, like Essen (Germany) and London, (England) where the wind direction controls the flow of pollutants in the surrounding areas [7] [17].

Daily fluctuations in $\mathrm{CO}_{2}$ and $\mathrm{CH}_{4}$ mixing ratios at the Heredia site were similar during October (wet season) and January (transition period). Figure 5 shows the daily $\mathrm{CO}_{2}$ and $\mathrm{CH}_{4}$ mixing ratios, at Heredia in October and January. The observed amplitude (114 - $122 \mathrm{ppm}$ for $\mathrm{CO}_{2}$ and $304-321 \mathrm{ppb}$ for $\mathrm{CH}_{4}$ ) and daily changes in the concentration of both gases followed the typical behavior reported at other urban areas, with the lower mixing 


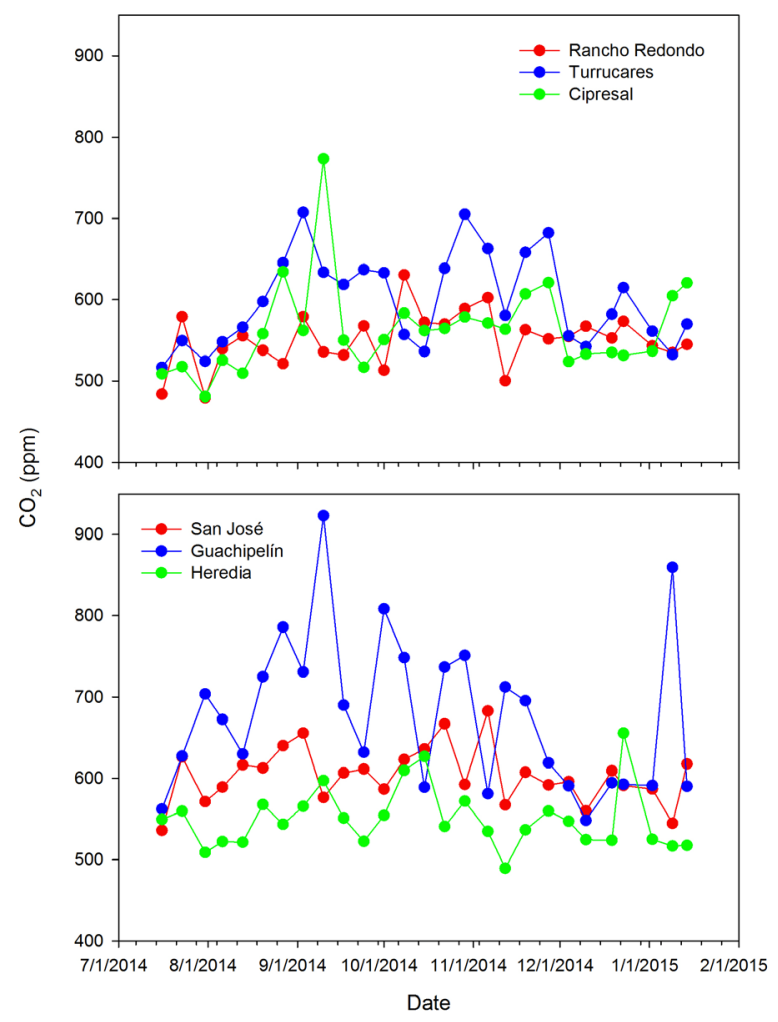

Figure 3. Seasonal variation of near surface carbon dioxide at the Central Valley’s rural sites (top) and urban sites (bottom).

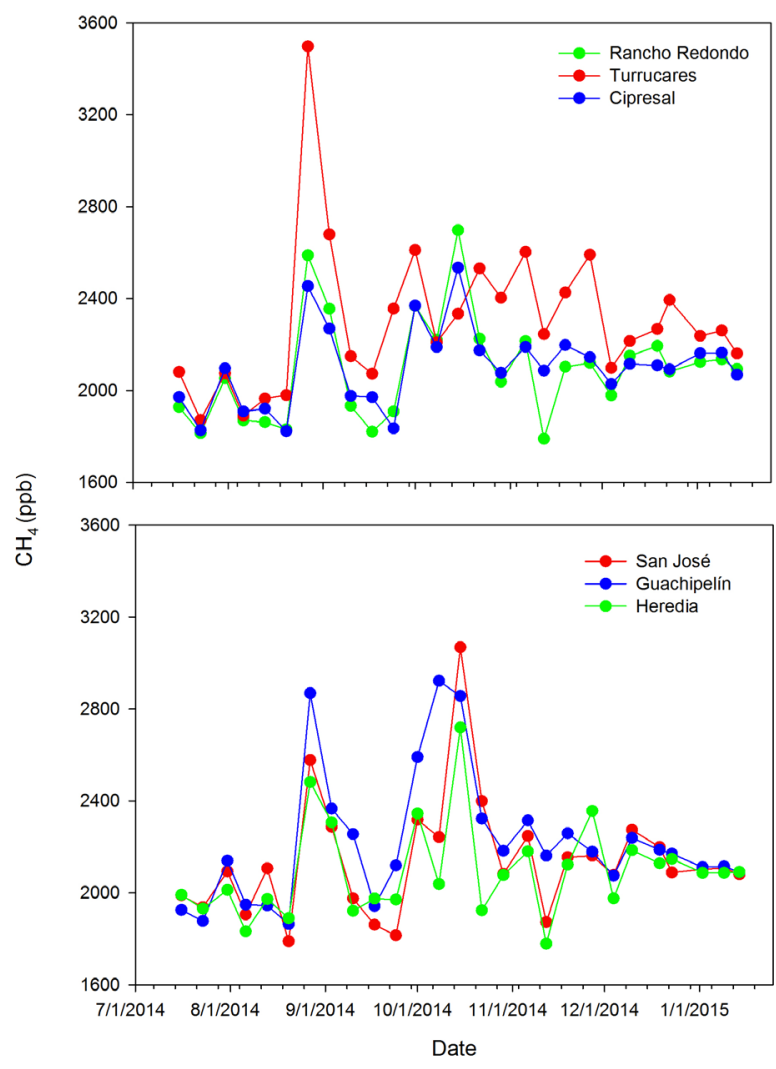

Figure 4. Seasonal variation of near surface methane at the Central Valley’s rural sites (top) and urban sites (bottom). 
Table 3. Summary of $\mathrm{CO}_{2}$ and $\mathrm{CH}_{4}$ mixing ratios (average $\pm \mathrm{SD}^{1}$ ) measured in the Central Valley during the three distinct seasons between July 2014 and January 2015.

\begin{tabular}{ccccccc}
\hline & \multicolumn{5}{c}{ Carbon dioxide (ppm) } \\
\hline Season & San José & Guachipelín & Heredia & Rancho Redondo & Turrúcares & Cipresal \\
\hline Mid-summer drought & $578 \pm 46$ & $631 \pm 71$ & $539 \pm 27$ & $514 \pm 56$ & $530 \pm 17$ & $502 \pm 19$ \\
Wet season & $618 \pm 34$ & $714 \pm 89$ & $555 \pm 37$ & $556 \pm 35$ & $618 \pm 53$ & $574 \pm 63$ \\
Transition period & $589 \pm 24$ & $631 \pm 94$ & $545 \pm 44$ & $554 \pm 12$ & $589 \pm 52$ & $568 \pm 43$ \\
\hline Season & & & Methane (ppb) & & Cipresal \\
\hline Mid-summer drought & $2007 \pm 79$ & $1981 \pm 140$ & $1978 \pm 42$ & $1932 \pm 119$ & $2009 \pm 119$ & $1965 \pm 135$ \\
Wet season & $2170 \pm 343$ & $2311 \pm 353$ & $2094 \pm 264$ & $2115 \pm 292$ & $2368 \pm 264$ & $2118 \pm 220$ \\
\hline Transition period & $2139 \pm 66$ & $2159 \pm 65$ & $2131 \pm 102$ & $2109 \pm 59$ & $2294 \pm 102$ & $2120 \pm 53$ \\
\hline
\end{tabular}

${ }^{1}$ SD: Standard deviation.

ratios recorded at mid-day, where the vertical mixing in the urban atmosphere is more effective [7] [19] [31]. Also, the seasonal influence on the $\mathrm{CO}_{2}$ and $\mathrm{CH}_{4}$ mixing ratios is very easy to observe in Figure 5. During January, the concentrations of both gases were lower than those recorded during October, as a result of changes in the atmospheric conditions during this season. These changes also resulted in greater variability in the urban levels during the transition period, especially during the late afternoon and early nighttime. The observed variability for methane, expressed as one standard deviation, was \pm 52 ppb during the transition period vs \pm 35 ppb during the wet season. Carbon dioxide deviations were $\pm 28 \mathrm{ppm}$ and $\pm 20 \mathrm{ppm}$, respectively. This can be related to a reduction in the boundary layer height as reported by some authors [4] [5] [13], or to an increase in the wind speed as discussed above. These results suggest that the atmospheric conditions, i.e., air mass origin, wind speed and direction, and vertical mixing, together with their seasonal variation, play an important role on the accumulation of $\mathrm{CO}_{2}$ and $\mathrm{CH}_{4}$ in the urban atmosphere over the Central Valley.

\subsection{Air Mass Back Trajectories Analysis and Vertical Mixing in the Urban Atmosphere}

The air masses $(n=27)$ that arrived over the Central Valley during the period of study were classified as shown in Figure 6, using the sampling site located in Heredia as a start location. During the mid-summer drought and the transition periods, the air masses can be described as fast-motion air parcels, moving along the NE-SW axis, as a result of the migration of the ITCZ to the north (mid-summer drought) and south (transition period) of Costa Rica [32]. Under the influence of such air masses, a mean mixing ratio of $588 \pm 67$ ppm for $\mathrm{CO}_{2}$ and $2073 \pm 124$ ppb for $\mathrm{CH}_{4}$ was recorded. During the wet season, the ITCZ are dominant in Costa Rica, and cross-equatorial winds from the southern hemisphere recurve to become southwesterly transporting slow-motion air masses in combination with weak trade winds from the Pacific Ocean to Costa Rica [33]. The mixing ratios measured under these conditions were $638 \pm 89 \mathrm{ppm}$ for $\mathrm{CO}_{2}$ and $2253 \pm 164 \mathrm{ppb}$ for $\mathrm{CH}_{4}$. According to the simulated trajectories and the mixing layer depths calculated by HYSPLIT, this transport pattern causes seasonal changes in the mixing layer depths over the Central Valley (Figure 7). The reduction of the mixing layer depth ( 425 m) and associated increasing mixing ratios of $\mathrm{CO}_{2}$ were strongest during the wet season. The relationship between both variables resulted in a moderate negative correlation for the data set $(\mathrm{n}=27)$, with a Pearson correlation coefficient $(\mathrm{r})$ of $-0.419(p=0.00938)$. An additional correlation was found between the $\mathrm{CO}_{2}$ mixing ratios and wind speed $(\mathrm{r}=-0.491, p=0.00927)$. Under this scenario, it is apparent that the local emissions of anthropogenic $\mathrm{CO}_{2}$ controls the buildup of $\mathrm{CO}_{2}$ over the metropolitan area, which is enhanced during the wet season by the gas mixing dynamics in the atmospheric boundary layer. As result of this process, human activities of the metropolitan area, i.e. fossil fuel combustion, automotive traffic, industrial activities (and their intensities), also influence the $\mathrm{CO}_{2}$ concentrations in the surrounding urban and rural sites.

When this analysis is applied to $\mathrm{CH}_{4}$, the corresponding mixing ratios seems to be influenced by the mixing layer depth too (Figure 7). The peak-to-peak amplitude of the variation in the concentration of $\mathrm{CH}_{4}$ is $941 \mathrm{ppb}$ 

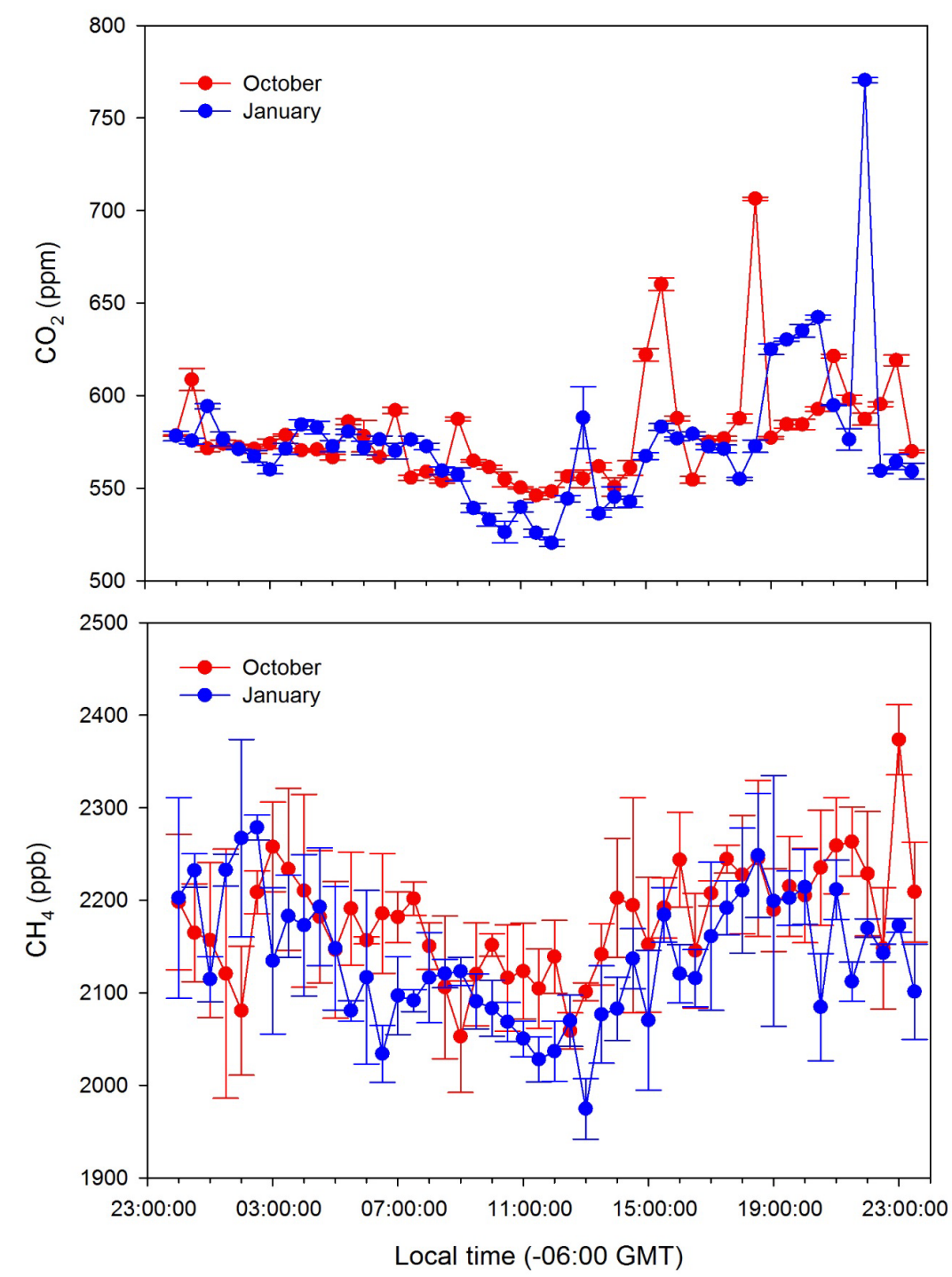

Figure 5. Diel patterns of carbon dioxide (top) and methane (bottom) recorded at the Heredia sampling site in October 2014 and January 2015.

and the concentrations show a high variability during the wet season ( $\pm 335 \mathrm{ppb}$ vs \pm 85 and $\pm 110 \mathrm{ppb}$ during the mid-summer drought and the transition season, respectively). However, and similar to the observed relationship found for the seasonal variation of mixing ratios inside the metropolitan area, no significant correlation was observed between the mixing layer depth and the $\mathrm{CH}_{4}$ mixing ratios $(\mathrm{r}=-0.190, p=0.342)$. This might be related to the existence of local anthropogenic $\mathrm{CH}_{4}$ sources releasing relatively large amounts of $\mathrm{CH}_{4}$ into the urban atmosphere, for example, sewage collectors, fossil fuel combustion and dumps [23].

Based on the above discussion, our data may suggest that a dome of high $\mathrm{CO}_{2}$ levels forms over the metropolitan area of Costa Rica. It seems apparent that during the wet season, when the wind speed across the valley decreases and the mixing layer depth reduces its height (reaching values as low as $200-250 \mathrm{~m}$ ), the local atmospheric mixing is considerably reduced. This results in relative high concentrations of $\mathrm{CO}_{2}$ and $\mathrm{CH}_{4}$, but also in an increase in the variability of the recorded mixing ratios (Table 3). This increase is even bigger than the largest surface $\mathrm{CO}_{2}$ increase of $5 \%$ (17.5 ppm), reported for a large urban conglomerate like Los Angeles [15]. This may also lead to the formation of an urban heat island in the metropolitan area; a phenomena that has coincided with high levels of $\mathrm{CO}_{2}$ in cities like Phoenix, Arizona [34]. However, due to the limited time period of this study (27 weeks), a longer period of sampling and analysis is needed to confirm the information presented here. 


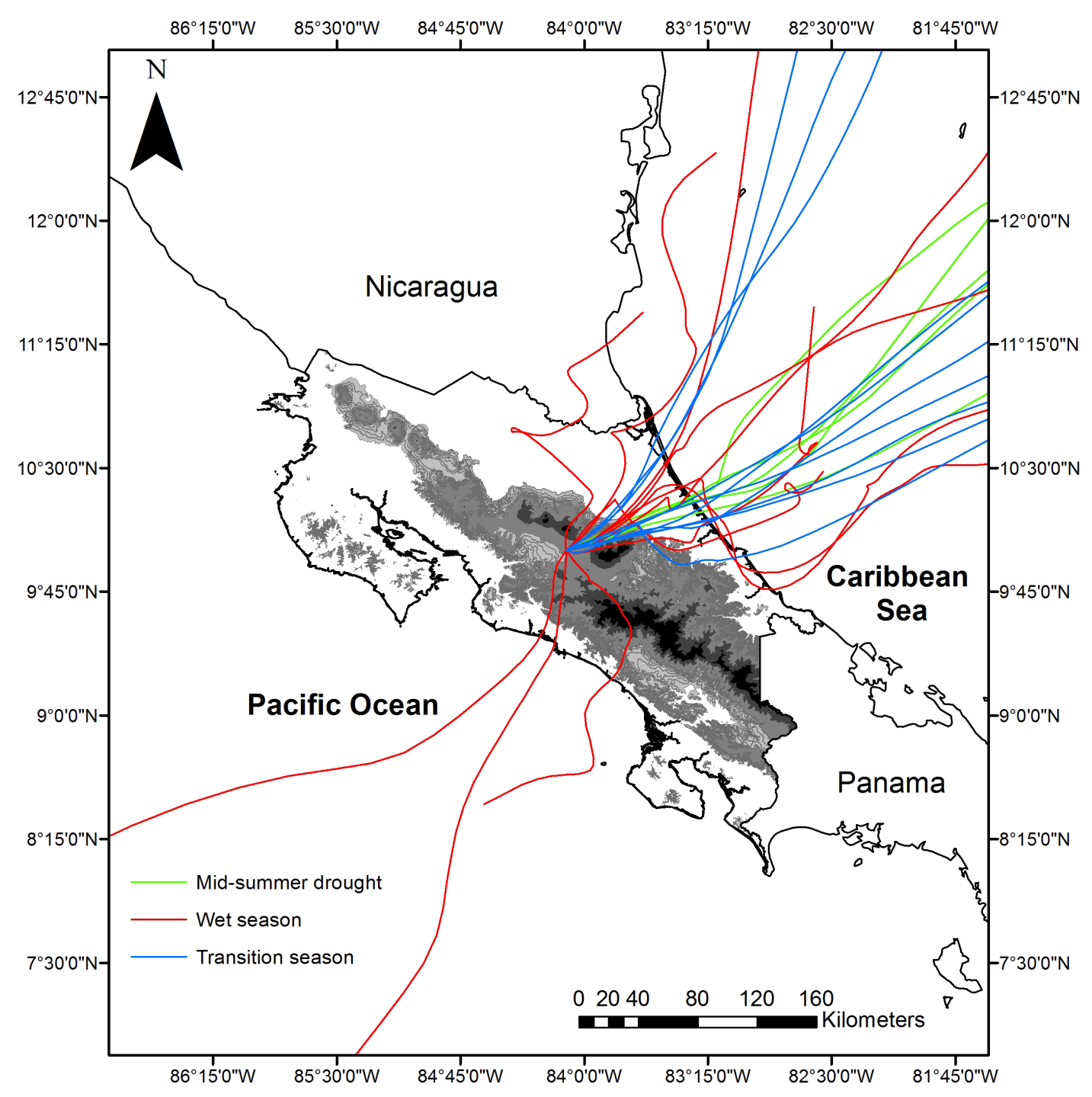

Figure 6. 48 hours air mass back trajectories calculated using HYSPLIT for weekly samples collected at the Heredia sampling site $(\mathrm{n}=27)$.

\subsection{Spatial Distribution of $\mathrm{CO}_{2}$ and $\mathrm{CH}_{4}$ during the Transition Period 2014-2015}

In contrast to the concentrations recorded at the urban and rural sites located outside the Central Valley (Figure 8 and Figure 9), the spatial distribution of $\mathrm{CO}_{2}$ and $\mathrm{CH}_{4}$ reveals a strong influence of anthropogenic activities in the valley. In the protected areas, for example, $\mathrm{CO}_{2}$ mixing ratios followed the concentration patterns reported in tropical forests of Brazil [35] [36]. However, there are some remarkable differences in the levels of both gases at some sites located outside the valley. Urban sites located near the Turrialba Volcano (Capellades and Pacayas) and the rural site located close to the crater, are influenced by the ongoing volcanic emissions, where the concentration of $\mathrm{CO}_{2}$ in the emitted gases was estimated at $4.03 \%$ mol [37]. In such urban sites, the volcanic plume can affect the local $\mathrm{CO}_{2}$ levels when the atmospheric circulation patterns cause the transport of volcanic-related emissions over the nearby populated areas [38]. The latter can also lead to an effective transport of such emissions into the Central Valley. Further investigations are needed to elucidate the impact of such emissions on the $\mathrm{CO}_{2}$ levels in the valley. At other sites, relative high levels of $\mathrm{CO}_{2}$ were also recorded, like in the southern region of Costa Rica (Golfito, Ciudad Neilly and Buenos Aires). This finding might be related to the typical traffic agglomeration inside these urban areas, resulting from poor road infrastructure that increases the vehicle-related pollutant emissions into the air. 

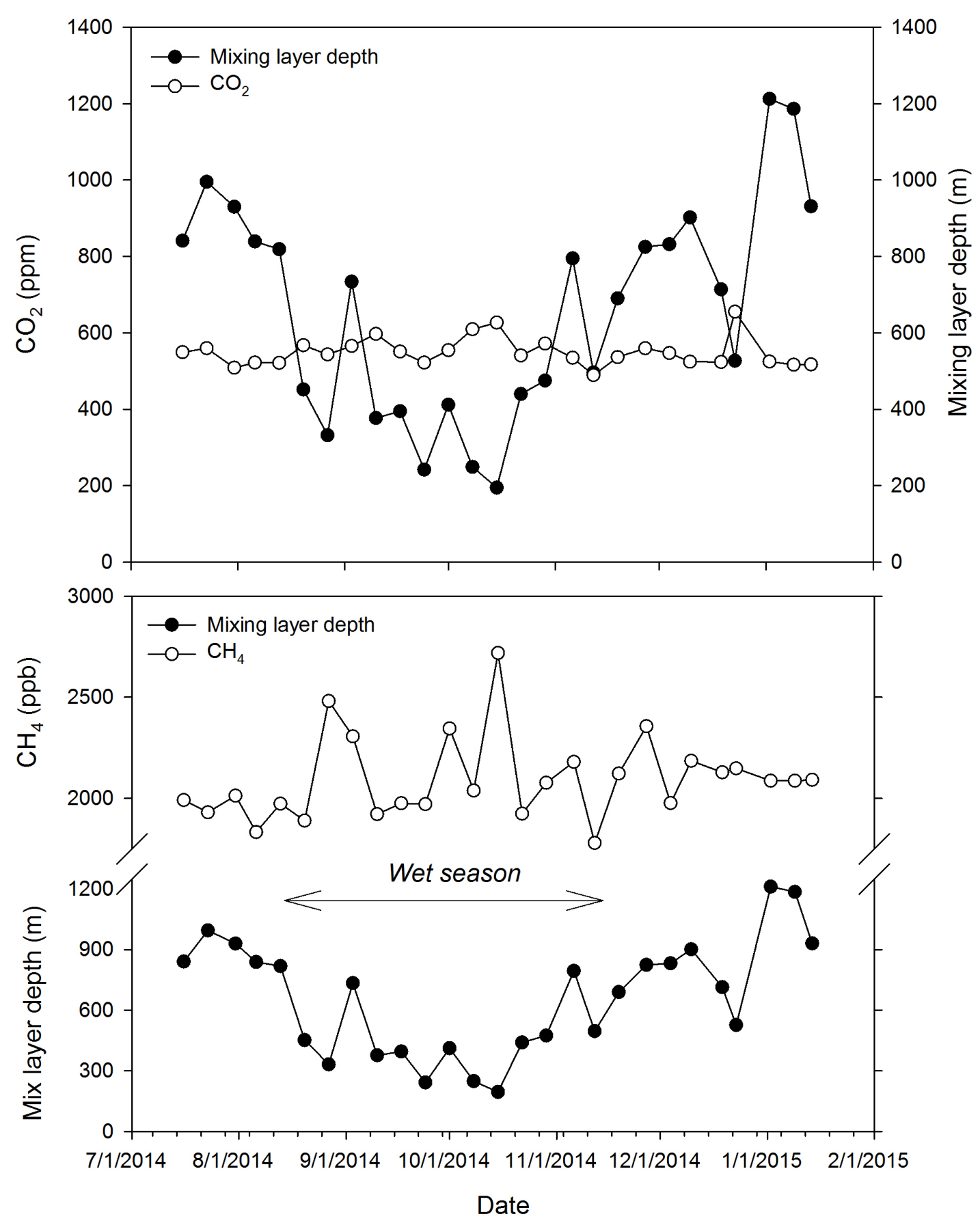

Figure 7. Seasonal variation of mixing layer depth at the Heredia sampling site and its influence on carbon dioxide (top) and methane concentrations (bottom).

$\mathrm{CH}_{4}$ mixing ratios were also influenced by natural and anthropogenic sources at several sites located outside the valley. The $\mathrm{CH}_{4}$ levels at the sampling sites located on the Santa Elena Peninsula (Murciélago and La Cruz) were influenced by natural sources that release $\mathrm{CH}_{4}$ into the atmosphere, such as the biological activity in wetlands (mangroves) located on the coast near La Cruz [23], and also emissions that arise from the active serpentinization process recently characterized in the Murciélago River [39]. Concentrations at other rural and urban sites might be influenced by local emissions originating from agricultural settings, where livestock activities are recognized sources of $\mathrm{CH}_{4}[40]$. 


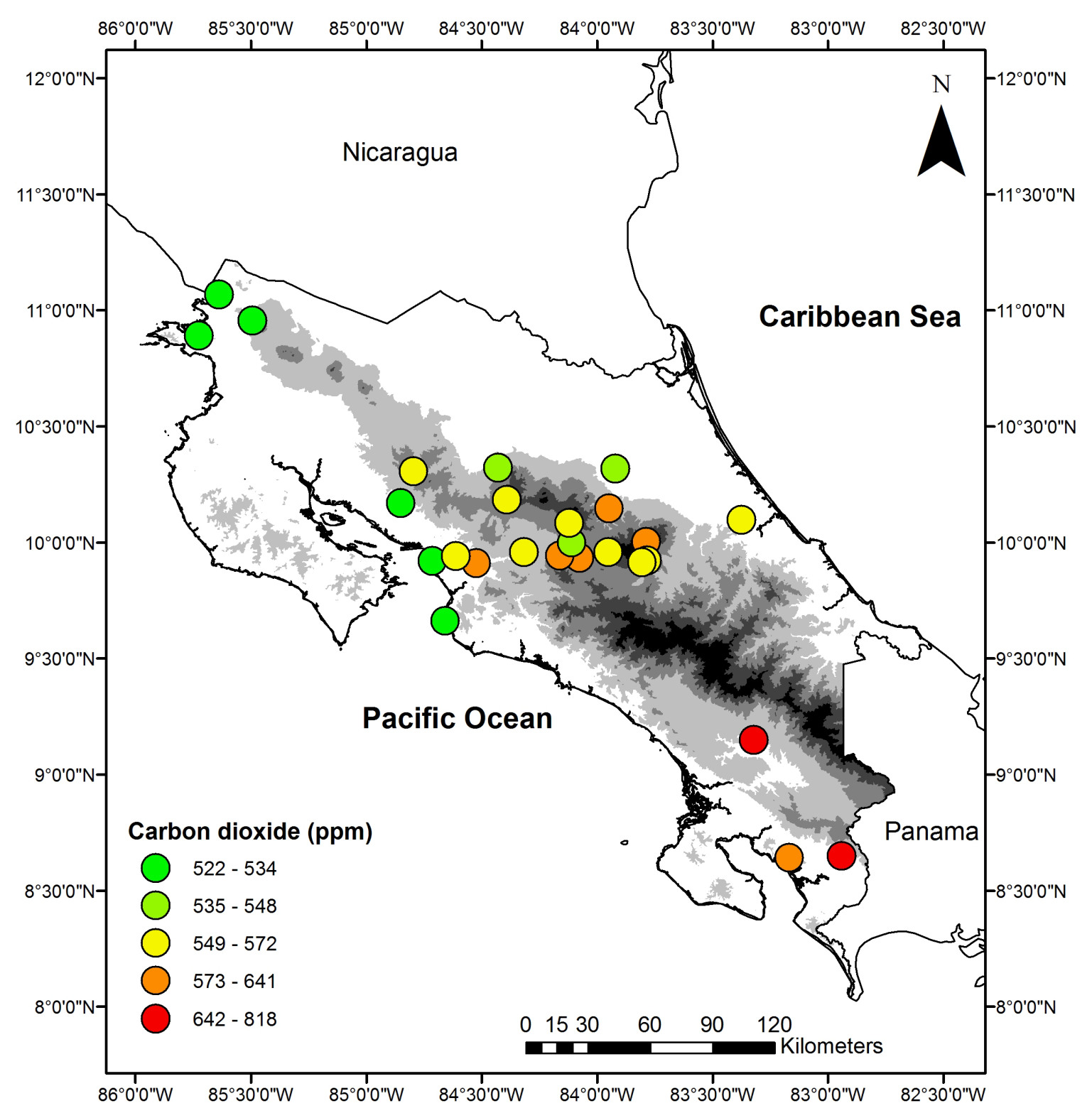

Figure 8. Spatial distribution of near surface carbon dioxide concentrations during December 2014 and January 2015.

\section{Conclusions}

This study focused on the characterization of spatial and temporal variability of near surface carbon dioxide $\left(\mathrm{CO}_{2}\right)$ and methane $\left(\mathrm{CH}_{4}\right)$ concentrations in the Central Valley of Costa Rica and at other representative urban and rural sites located across the country. The results indicate that the anthropogenic activities in the metropolitan area, and the Central Valley as a whole, control the mixing ratios of both GHG. Despite the proximity of the study sites in the valley (ca. $30 \mathrm{~km}$ ), it is obvious that the populated areas located along the S-SW-W axis of the metropolitan area are influenced by the transported emissions of $\mathrm{CO}_{2}$ and $\mathrm{CH}_{4}$, which increases the levels of both gases in these areas. Seasonal influences were clearly visible in the data presented, affecting both short- and long term changes in $\mathrm{CO}_{2}$ and $\mathrm{CH}_{4}$ concentrations due to a reduction in the mixing layer depth and wind speed across the valley during the wet season. Despite the limited time period of this study to represent seasonal conditions in the Central Valley during 2014 and 2015 (27 weeks), our data provide the first indication that the "dome" phenomenon exists in Costa Rica's metropolitan areas. A long-term analysis of $\mathrm{CO}_{2}$ concentrations in air is needed to confirm the information presented here. 


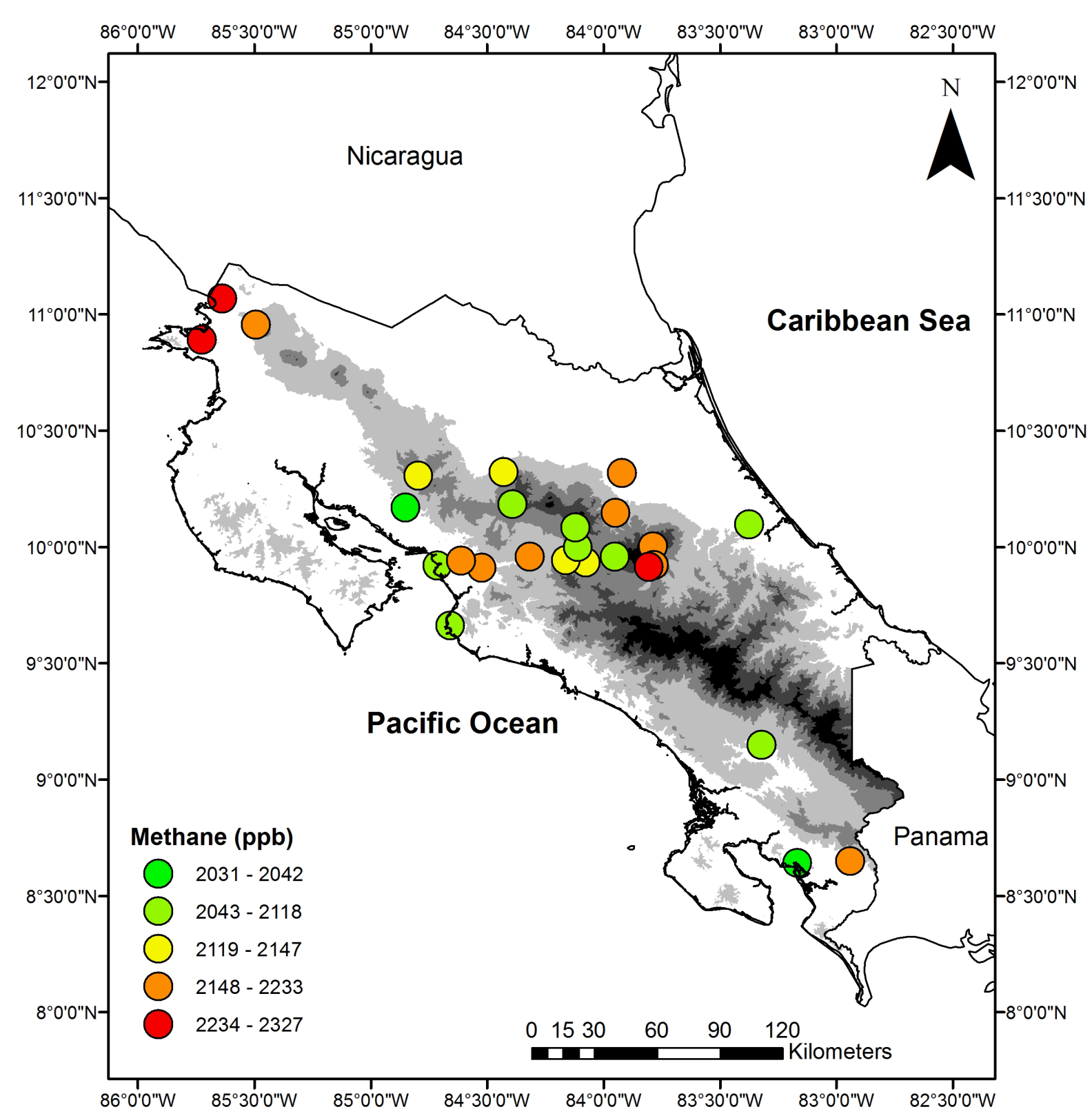

Figure 9. Spatial distribution of near surface methane concentrations during December 2014 and January 2015.

The $\mathrm{CO}_{2}$ mixing ratios measured in the Central Valley showed almost permanent excess levels of this gas when compared to other urban and rural sites, although some sites, like those located near volcanic activity, were clearly influenced by the local volcanic emissions. It was also apparent that the $\mathrm{CH}_{4}$ mixing ratios in some sites are affected by specific processes, e.g., wetland and geochemical-related gaseous emissions. It also appears that agricultural and livestock activities impacted the near surface concentration of $\mathrm{CH}_{4}$ at rural sites. However, our analysis does not identify specifically the sources of $\mathrm{CO}_{2}$ and $\mathrm{CH}_{4}$, emissions. To do so, an intensive sampling campaign that includes isotopic analysis $\left({ }^{13} \mathrm{C}\right.$ for example) in different areas of the Central Valley and surrounding regions would be required. Similar analysis at other urban areas in the Central American region would help define the robustness of the data presented and may also help identify the emission sources.

\section{Acknowledgements}

The authors thank F. Ovares, P. Campos and R. Bulgarelli for their logistical support to get access to the field 
sites in Cipresal, Guachipelín and Turrúcares, respectively. Funding provided by the National University of Costa Rica was essential to acquire the GC used in this study. We also thank the personnel of Grupo de Investigaciónen Isotopos Estables (L. Corrales) for their assistance with air samples collection.

\section{References}

[1] Liu, L., Zhou, L., Zhang, X., Wen, M., Zhang, F., Yao, B. and Fang, S. (2009) The Characteristics of Atmospheric CO Concentration Variation of Four National Background Stations in China. Science in China Series D: Earth Sciences, 52, 1857-1863. http://dx.doi.org/10.1007/s11430-009-0143-7

[2] Nisbet, E. and Manning, M. (2009) The Global Atmosphere: Greenhouse Gases and Urban Pollution. WMO Bulletin, 58, $1-5$.

[3] Wang, Y.S., Wang, M.X., Luo, D.M., Zheng, X.H. and Zhou, L. (2000) Trend and Seasonal Variations of Atmospheric Methane in Beijing. Journal of Environmental Sciences, 12, 369-374.

[4] Wang, Y., Wang, C., Guo, X., Liu, G. and Huang, Y. (2002) Trend, Seasonal and Diurnal Variations of Atmospheric $\mathrm{CO}_{2}$ in Beijing. Chinese Science Bulletin, 47, 2050. http://dx.doi.org/10.1360/02tb9444

[5] Vinogradova, A.A., Fedorova, E.I., Belikov, I.B., Ginzburg, A.S., Elansky, N.F. and Skorokhod, A.I. (2007) Temporal Variations in Carbon Dioxide and Methane Concentrations under Urban Conditions. Izvestiya, Atmospheric and Oceanic Physics, 43, 599-611. http://dx.doi.org/10.1134/S0001433807050088

[6] Wunch, D., Wennberg, P.O., Toon, G.C., Keppel-Aleks, G. and Yavin, Y.G. (2009) Emissions of Greenhouse Gases from a North American Megacity. Geophysical Research Letters, 36, L15810. http://dx.doi.org/10.1029/2009gl039825

[7] Henninger, S. and Kuttler, W. (2010) Near Surface Carbon Dioxide within the Urban Area of Essen, Germany. Physics and Chemistry of the Earth, 35, 76-84. http://dx.doi.org/10.1016/j.pce.2010.03.006

[8] Lietzke, B. and Vogt, R. (2013) Variability of CO2 Concentrations and Fluxes in and above an Urban Street Canyon. Atmospheric Environment, 74, 60-72. http://dx.doi.org/10.1016/j.atmosenv.2013.03.030

[9] Mills, G. (2007) Cities as Agents of Global Change. International Journal of Climatology, 27, 1849-1857. http://dx.doi.org/10.1002/joc.1604

[10] Gioli, B., Toscano, P., Lugato, E., Matese, A., Miglietta, F., Zaldei, A. and Vaccari, F.P. (2012) Methane and Carbon Dioxide Fluxes and Source Partitioning in Urban Areas: The Case Study of Florence, Italy. Environmental Pollution, 164, 125-131. http://dx.doi.org/10.1016/j.envpol.2012.01.019

[11] Pataki, D.E., Tyler, B.J., Peterson, R.E., Nair, A.P., Steenburgh, W.J. and Pardyjak, E.R. (2005) Can Carbon Dioxide Be Used as a Tracer of Urban Atmospheric Transport? Journal of Geophysical Research, 110, Article ID: D15102. http://dx.doi.org/10.1029/2004JD005723

[12] Roth, M. (2007) Review of Urban Climate Research in (Sub)Tropical Regions. International Journal of Climatology, 27, 1859-1873. http://dx.doi.org/10.1002/joc.1591

[13] Popa, M.E., Gloor, M., Manning, A.C., Jordan, A., Schultz, U., Haensel, F., Seifert, T. and Heimann, M. (2010) Measurements of Greenhouse Gases and Related Tracers at Bialystok Tall Tower Station in Poland. Atmospheric Measurement Techniques, 3, 407-427. http://dx.doi.org/10.5194/amt-3-407-2010

[14] Velasco, E., Perrusquia, R., Jiménez, E., Hernández, F., Camacho, P., Rodríguez, S., Retama, A. and Molina, L.T. (2014) Sources and Sinks of Carbon Dioxide in a Neighborhood of Mexico City. Atmospheric Environment, 97, 226238. http://dx.doi.org/10.1016/j.atmosenv.2014.08.018

[15] Jacobson, M. (2010) Enhancement of Local Air Pollution by Urban $\mathrm{CO}_{2}$ Domes. Environmental Science and Technology, 44, 2497-2502. http://dx.doi.org/10.1021/es903018m

[16] Idso, C.D., Idso, S.B. and Balling Jr., R.C. (1998) The Urban $\mathrm{CO}_{2}$ Dome of Phoenix, Arizona. Physical Geography, 19, 95-108.

[17] Lowry, D., Holmes, C.W. and Rata, N.D. (2001) London Methane Emissions: Use of Diurnal Changes in Concentration and $\delta^{13} \mathrm{C}$ to Identify Urban Sources and Verify Inventories. Journal of Geophysical Research, 106, 7427-7448. http://dx.doi.org/10.1029/2000JD900601

[18] Pataki, D.E., Bowling, D.R. and Ehleringer, J.R. (2003) Seasonal Cycle of Carbon Dioxide and Its Isotopic Composition in an Urban Atmosphere: Anthropogenic and Biogenic Effects. Journal of Geophysical Research, 108, 4735. http://dx.doi.org/10.1029/2003JD003865

[19] Chmura, L., Rozanski, K., Necki, J.M., Zimnoch, M., Kuc, T. and Korus, A. (2005) Atmospheric Concentrations of Carbon Dioxide and Its Isotopic Composition in Southern Poland: Comparison of High-Altitude Mountain Site and a Near-By Urban Environment. Biogeosciences Discussions, 2, 1849-1865. http://dx.doi.org/10.5194/bgd-2-1849-2005 
[20] Forster, P., Ramaswamy, V., Artaxo, P., Berntsen, T., Betts, R., Fahey, D.W., Haywood, J., Lean, J., Lowe, D.C., Myhre, G., Nganga, J., Prinn, R., Raga, G., Schulz, M. and Van Dorland, R. (2007) Changes in Atmospheric Constituents and in Radiative Forcing. In: Solomon, S., Qin, D., Manning, M., Chen, Z., Marquis, M., Averyt, K.B., Tignor, M. and Miller, H.L., Eds., Climate Change 2007: The Physical Science Basis. Contribution of Working Group I to the Fourth Assessment Report of the Intergovernmental Panel on Climate Change, Cambridge University Press, Cambridge and New York.

[21] Sinha, V., Williams, J., Crutzen, P.J. and Lelieveld, J. (2007) Methane Emissions from Boreal and Tropical Forest Ecosystems Derived from In-Situ Measurements. Atmospheric Chemistry and Physics Discussions, 7, 14011-14039. http://dx.doi.org/10.5194/acpd-7-14011-2007

[22] Townsend-Small, A., Tyler, S.C., Pataki, D.E. and Xu, X. (2012) Isotopic Measurements of Atmospheric Methane in Los Angeles, California, USA: Influence of “Fugitive” Fossil Fuel Emissions. Journal of Geophysical Research, 117, Article ID: D07308. http://dx.doi.org/10.1029/2011JD016826

[23] Gorka, M., Lewicka-Szczebak, D., Fus, R., Jakubiak, M. and Jedrysek, M.O. (2014) Dynamics and Origin of Atmospheric $\mathrm{CH}_{4}$ in a Polish Metropolitan Area Characterized by Wetlands. Applied Geochemistry, 45, 72-81. http://dx.doi.org/10.1016/j.apgeochem.2014.03.007

[24] Sikar, E. and La Skala Jr., N. (2004) Methane and Carbon Dioxide Seasonal Cycles at Urban Brazilian Inland Sites. Journal of Atmospheric Chemistry, 47, 101-106. http://dx.doi.org/10.1023/B:JOCH.0000021027.42511.ef

[25] Griffin, T.P., Diaz, J.A., Arkin, C.R., Soto, C., Curley, C.H. and Gomez, O. (2008) Three-Dimensional Concentration Mapping of Gases Using a Portable Mass Spectrometer System. Journal of the American Society for Mass Spectrometry, 19, 1411-1418. http://dx.doi.org/10.1016/j.jasms.2008.05.020

[26] Villalobos-González, W., Esquivel-Hernández, G., Sánchez-Murillo, R., Corrales-Salazar, J.L. and Valdés-González, J. (2015) Analysis of Benzene Exposure Levels on Commuters Traveling within the Metropolitan Area of Costa Rica. Open Journal of Air Pollution, 4, 38-46. http://dx.doi.org/10.4236/ojap.2015.41005

[27] Sánchez-Murillo, R., Esquivel-Hernández, G., Welsh, K., Brooks, E.S., Boll, J., Alfaro-Solís, R. and Valdés-González, J. (2013) Spatial and Temporal Isotopic Variations of Precipitation in Costa Rica: An Analysis of Historic GNIP Records. Modern Hydrology, 3, 226-240. http://dx.doi.org/10.4236/ojmh.2013.34027

[28] Waylen, M.E. (1996) Interannual Variability of Monthly Precipitation in Costa Rica. Journal of Climate, 9, $2606-2613$. http://dx.doi.org/10.1175/1520-0442(1996)009<2606:IVOMPI>2.0.CO;2

[29] Magaña, V., Amador, J.A. and Medina, S. (1999) The Midsummer Drought over Mexico and Central America. Journal of Climate, 12, 1577-1588. http://dx.doi.org/10.1175/1520-0442(1999)012<1577:TMDOMA>2.0.CO;2

[30] Draxler, R.R. and Rolph, G.D. (2015) HYSPLIT (HYbrid Single-Particle Lagrangian Integrated Trajectory) Model Access via NOAA ARL READY Website (http://www.arl.noaa.gov/HYSPLIT.php) on February 24th, 2015. NOAA Air Resources Laboratory, College Park.

[31] Pataki, D.E., Bowling, D.R., Ehleringer, J.R. and Zobitz, J.M. (2006) High Resolution Atmospheric Monitoring of Urban Carbon Dioxide Sources. Geophysical Research Letters, 33, Article ID: L03813. http://dx.doi.org/10.1029/2005GL024822

[32] Duran-Quesada, A.M., Gimeno, L., Amador, J.A. and Nieto, R. (2010) Moisture Sources for Central America: Identification of Moisture Sources Using a Lagrangian Analysis Technique. Journal of Geophysical Research, 115, Article ID: D05103. http://dx.doi.org/10.1029/2010jd014168

[33] Poveda, G., Waylen, P.R. and Pulwarty, R.S. (2006) Annual and Inter-Annual Variability of the Present Climate in Northern South America and Southern Mesoamerica. Palaeogeography, Palaeoclimatology, Palaeoecology, 234, 3-27. http://dx.doi.org/10.1016/j.palaeo.2005.10.031

[34] Balling Jr., R.C., Cerveny, R.S. and Idso, C.D. (2001) Does the Urban $\mathrm{CO}_{2}$ Dome of Phoenix, Arizona Contribute to Its Heat Island? Geophysical Research Letters, 28, 4599-4601. http://dx.doi.org/10.1029/2000GL012632

[35] Goulden, M.L., Miller, S.D., da Rocha, H.R., Menton, M.C., de Freitas, H.C., Silva Figueira, A.M. and Dias de Sousa, C.A. (2004) Diel and Seasonal Patterns of Tropical Forest $\mathrm{CO}_{2}$ Exchange. Ecological Applications, 14, S42-S54.

[36] de Araújo, A.C., Kruijt, B., Nobre, A.D., Dolman, A.J., Waterloo, M.J., Moors, E.J. and de Souza, J.S. (2008) Nocturnal Accumulation of $\mathrm{CO}_{2}$ Underneath a Tropical Forest Canopy along a Topographical Gradient. Ecological Applications, 18, 1406-1419. http://dx.doi.org/10.1890/06-0982.1

[37] Moussallam, Y., Peters, N., Ramírez, C., Oppenheimer, C., Aiuppa, A. and Giudice, G. (2014) Characterisation of the Magmatic Signature in Gas Emissions from Turrialba Volcano, Costa Rica. Solid Earth, 5, 1341-1350. http://dx.doi.org/10.5194/se-5-1341-2014

[38] Granieri, D., Costa, A., Macedonio, G., Bisson, M. and Chiodini, G. (2013) Carbon Dioxide in the Urban Area of Naples: Contribution and Effects of the Volcanic Source. Journal of Volcanology and Geothermal Research, 260, 5261. http://dx.doi.org/10.1016/j.jvolgeores.2013.05.003 
[39] Sánchez-Murillo, R., Gazel, E., Schwarzenbach, E.M., Crespo-Medina, M., Schrenk, M.O., Boll, J. and Gill, B.C. (2014) Geochemical Evidence for Active Tropical Serpentinization in the Santa Elena Ophiolite, Costa Rica: An Analog of a Humid Early Earth? Geochemistry, Geophysics, Geosystems, 15, 1783-1800. http://dx.doi.org/10.1002/2013gc005213

[40] Lelieveld, J., Crutzen, P.J. and Dentener, F.J. (1998) Changing Concentration, Lifetime and Climate Forcing of Atmospheric Methane. Tellus, 50B, 128-150. http://dx.doi.org/10.1034/j.1600-0889.1998.t01-1-00002.x

[41] Sánchez-Murillo, R., Birkel, C., Welsh, K., Esquivel-Hernández, G., Corrales-Salazar, J., Boll, J., Brooks, E., Roupsard, O., Sáenz-Rosales, O., Katchan, I., Arce-Mesén, A., Soulsby, C. and Araguás-Araguás, L.J. (2015) Key Drivers Controlling Stable Isotope Variations in Daily Precipitation of Costa Rica: Caribbean Sea versus Eastern Pacific Ocean Moisture Sources. Quaternary Science Reviews, In Press. http://dx.doi.org/10.1016/j.quascirev.2015.08.028 